\title{
Plan Plus, Volume-10, $2020(37-58)$ \\ PHYSICAL UPGRADING OF HOUSING IN INFORMAL SETTLEMENTS: PRIORITIES FOR THE EXTREME POOR
}

\author{
Sheikh Serajul Hakim*1, Md. Azharul Islam ${ }^{2}$, Asrafi Bintay Akram ${ }^{3}$, Hridita \\ Podder Deepa ${ }^{4}$, Nilufar Shabnom Doni ${ }^{5}$, Ishmat Ara ${ }^{6}$, Nipa Debnath ${ }^{7}$ \\ 1. *Corresponding Author: Professor, Architecture Discipline, Khulna University. Email: serajulhakim@arch.ku.ac.bd \\ 2. Lecturer, Architecture Discipline, Khulna University \\ 3. Assistant Professor, Department of Sociology, Hajee Mohammad Danesh Science and Technology University, Dinajpur-5200 \\ 4.Lecturer, Architecture Department, NUBT, Khulna \\ 5.Graduate student, Architecture Discipline, Khulna University \\ 6.Adjunct Faculty, Architecture Department, NUBT, Khulna \\ 7.Graduate student, Architecture Discipline, Khulna University
}

\begin{abstract}
Informal settlements are home to nearly a quarter of global urban population - many of which are extreme poor. Prompted by both local and global initiatives and executed by donors and NGOs, these settlements have been undergoing infrastructural upgrading for the past 4-5 decades. Yet, the number of extreme poor and their settlements increased, while their overall livelihood situation remained unchanged. Hence, one becomes skeptical about the usefulness of these mostly settlement-level infrastructural upgrading works and asks about their right focus. Infrastructural development often also appear less useful for this group as their priorities are guided by market-led principles - planned and executed in a top down manner, while at the ground level, the extreme poor people having to deal with other 'smaller' housing and non-housing issues at the household/dwelling level. In the physical upgrading of informal settlements, extreme poor dwellers' such 'smaller' needs are therefore seldom prioritized. But being aware of these peoples' exact needs and priorities, and their inabilities to afford dwellingupgrading and their non-housing livelihood needs governing their priorities, we would still like to underscore if some contextual housing priorities can still be identified for future upgrading works. But in the broader context, we would also like to see why uncritical and un-contextual housing interventions are still conceptualized without considering extreme poor's needs? We used a case study approach for this research and studied two extreme poor settlements in Khulna, Bangladesh. We found that no intervention so far prioritized the dwelling-unit with the goal to improving their livelihoods. Key constraints behind this were the lack of tenure security, chronic exposure to natural hazards, high renter-owner ratio, not enough investments in non-monetary livelihood dimensions, and missing HBE components in housing credit. Issues regarding beneficiary selection, appreciation of extreme poor peoples' capacities and practices, prioritizing non-housing needs, absence of incremental upgrading schemes and housing not being considered as key livelihood instrument also compounded the matter. We realized that market-driven neoliberal principles that advocate state withdrawal and privatization had played a key role in setting priorities for the donors, NGOs and even local government bodies. We suggested that physical upgrading priority for the extreme poor should hence be set in two mutually dependent fronts. One, a continuation of UPPR's partnership approach should be ensured, supplemented by subsidies. This needs to be extended more into housing/dwelling levels. For the poorest and the most vulnerable, a greater presence of Government in providing social safety nets also need to be provisioned simultaneously. Two, livelihood dimensions need to be mainstreamed and integrated with all housing and non-housing upgrading.
\end{abstract}

KEYWORDS: Informal Settlement, Physical Upgrading, Priority, Livelihood, Housing Infrastructure, Khulna 


\section{INTRODUCTION}

More people are living in extreme poverty in urban Bangladesh now (11.5\%) compared to 2010 (18\%), and this number should grow even more by 2030 (Hill et al., 2019). Around 40 million Bangladeshi live below the national poverty line, and as many as 120 million (76\% of the population) subsist below the international poverty line of $\$ 1.90 /$ day (UN, 2016). Quite naturally, urban informal settlements, which lack heavily of a number of social, spatio-physical and legal issues, remain many of these peoples' primary residential destination. In the sheer absence of formal sector housing delivery of any sorts, informal settlement upgrading hence has remained the predominant mode of housing provisioning for these type of urban poor since 1980s (Jaitman \& Brakarz, 2013). This aligns with MDGs' Goal 7, target 11, which previously promised to improve living conditions of informal settlement populations. This also coincides with SDG 11.1, reaffirming that by 2030, the world should strive to ensure access to adequate, safe and affordable housing and basic services for all, and hence keep upgrading informal settlements (UN, 2015).

Informal settlement upgrading, nevertheless, has been mostly sectoral (Jaitman \& Brakarz, 2013), and these sectoral interventions are often top-down, guided by donor agency priorities and implemented within the framework of time-budget limitations. Such interventions, despite all their successes, also have masked household- and dwelling-level needs and priorities of the dweller, and often failed to contribute to any significant upgrading of dwellers' livelihoods (Mpembamoto et al., 2017). John Turner has also echoed similar in the Needs and Priorities section of his seminal work Housing by People, that "Gross mismatches of housing priorities and housing obtained can be lethal", he said, "however well-intentioned, the imposition of standardized housing on the false basis of officially presumed 'needs' is potentially murderous" (Turner, 1976). However, in terms of 'needs' and despite much have been said in the non-dwelling needs of upgrading globally, not much work been done on the physical improvements house/dwelling that is based on the priority needs of informal settlement dwellers (Werthmann \& Beardsley, 2008).

Prioritization of spatio-physical tasks and activities, especially those enhance livelihood opportunities and aid income generation often remain missing. This holds particularly true for the poorest and where all types are poverty are considered homogeneously. UN Habitat (2003) highlights only the issue of "structural quality/durability of dwellings" and "sufficient living area" as two key physical dimensions of informal settlement upgrading. Informal settlement Almanac (UN Habitat, 2016), on the other hand, identifies space, privacy, durability and public space as some key spatio-physical areas of deprivation for informal settlement dwellers, in addition to the non-spatial issues like water supply, sanitation, services, health, education, livelihoods and mobility/connectivity. But none of these key documents, for example, discusses the need for home-based works or income generation (Gough \& Kellet, 2001; Ghafur, 2001; Tipple, 2005) or livelihood integration (Mpembamoto et al., 2017) concerning the spatio-physical dimensions of informal settlement upgrading.

Informal settlement upgrading began in Bangladesh in the mid-1980s primarily through the improvement of drainage and sanitation. Later the focus shifted to tenure security, which, 
together with the previous efforts, could not fully resolve informal settlement dwellers' housing problems (Mohit, 2012). In UNDP's ongoing NUPRP (National Urban Poverty Reduction Programme), the project aims to provide housing support towards balanced and sustainable growth and reduction of urban poverty. A seed fund called CHDF (Community Housing Development Fund) is presently being processed, which should provide dwelling improvement support to the poor. No details of the loan are not published yet. Moreover, even if loans are available, it is the poorest, who, without any regular income and payback capacities, appear to be the most ineligible in availing housing loans as seen elsewhere (Lucci et al., 2015). One realizes that knowing their dwelling-level priorities and actual needs are most important in making them eligible, even if partially, for these assistances.

There are about 1134 informal settlements within Khulna City Corporation (KCC), which comprise $8.14 \%$ of its total area (Alam \& Mondal, 2019). These informal settlements are home to $20 \%$ of Khulna city population, which, prompted by local and global initiatives, should undoubtedly come under various upgrading schemes in future. However, despite being aware of these extreme poor's inabilities in affording dwelling upgrading and their non-housing livelihood needs governing their priorities, we would still like to understand if there is anyway some contextual housing priorities can be identified and integrated into future upgrading initiatives. But in relation to a broader context, we would also like to ask why uncritical (and often un-contextual) housing interventions as such are still conceptualized without considering the poorest's needs? With these queries, we pursue the following three objectives. These are:

i. To find out how dwellers' needs are prioritized in different physical upgrading schemes in the selected informal settlements of Khulna.

ii. To identify the key constraints in setting priorities for physical upgrading at the dwelling level, especially for the extreme poor dwellers.

iii. To determine the physical upgrading priorities for the benefit of extreme poor dwellers, based on their housing and non-housing needs.

In terms of the article structure, the following section presents the relevant literature review around the thematic area of physical upgrading of informal settlements, followed by the methodology section. Findings in line with the stated objectives are presented in the next section, before we attempted to answer, based on the findings, why typical and uncritical housing interventions continue to occur that homogenizes all people and their capabilities.

\section{THEMATIC AREAS OF PHYSICAL UPGRADATION OF INFORMAL SETTLEMENTS}

\subsection{Challenges of 'physical upgrading' in informal settlements}

'Physical upgrading' usually refers to housing and/or basic infrastructure improvements in urban informal settlements. But in a wider sense, it also implies improvements in the socio-economic processes that can bring about such physical improvements (UN Habitat, 2014,). Yet, upgrading measures had typically demonstrated the tendency to view all poor evenly, without considering that these dwellers with different socio-economic abilities have different needs and priorities, and it is often while upgrading these priorities of the poorest are overlooked. Satterthwaite \& Mitlin (2013) asserts that not only the measures but also how the stakeholders' physical upgrading needs are prioritized are equally important. 
The political setback is also a key catalyst in upgrading. Informal settlements are fertile grounds for cultivation of political patron-client networks and rent-seeking behavior (Fox, 2014). As a result, political will and agendas for formalization of settlements and informal settlement upgrading are often quite complex. Patron-client relationships between political parties and people make provision of public services by political agents to a large segment of voters difficult (Keefer \& Khemani, 2004). Although the market driven approach seeks to resolve the housing problem of the informal settlement dwellers to a certain extent, the policies and actions are often inadequate in reaching the poorest.

Reaching these poorest has often proved to be quite difficult. Finding out suitable approaches to cater to the needs of the most marginalized is also essential. In fact, targeting particular settlements or population for upgrading should always be need-based. In most cases, the financing model reflects that it is more difficult for the poorest to take part. Therefore, the program should include provisions for the poorest - focusing on the older and disabled, rental houses or rooms for those who cannot afford/pay for upgrading, and building shelters for the homeless (Boonyabancha, 2009). This makes sure the poorest can live within their known community and work toward long-term upgrading even if they cannot immediately afford to upgrade within the given socio-economic framework physically.

Due to the complexities in defining an informal settlement typology (especially pertaining to tenure), varying needs of the dwellers and their unique political-economies, upgrading never had a universal solution structure. Previously, Turner $(1972,1976)$ urged the state to abstain from direct provisioning of housing (housing as a product), and focus instead on delivering services and infrastructure to enable dwellers and ensure autonomy (housing as a process). This instigated the novel sites and services initiatives in the $1970 \mathrm{~s}$, followed by various housing reforms and private sector housing finance programs backed by the World Bank in 1980s (Ramsamy, 2006). The physical upgrading of informal settlements and its 'market turn' under the broader umbrella of Urban Development hence calls for the recognition of the underlying politics of international urban development and housing. Under Structural Adjustment, the shelter was viewed as part of a social sector that did not directly contribute to export earnings for the given country. In accordance with the Bank's (and its allies') de-emphasis of the role of the state, the recent New Urban Agenda championed privatization and targeted the dismantling of public sector housing, arguing that it was inefficient and ineffective in addressing the housing needs of the urban poor. Presently, with increased emphasis on private property and market institutions focusing on the supply side, a dramatic expansion of the problem of informal settlements as a question of secured finance has been noticed with its ramification of the initiatives regarding 'bankable informal settlement up-gradation' (Ramsamy, 2006). Generally, there has been an increasing tendency, which began in the 1970 s to emphasize neoliberal and market-led principles - resembling the Anglo-American model. None of these, however, could resolve the issues of poverty, living cost and employment (Jones, 2012). These invariably instigate the debate on the politics of developmentalism, which stemmed from post-WWII aid projects inspired by modernization theories and targeting underdevelopment with a linear view of progress (Wong, 2017). 


\subsection{Missed opportunities in informal settlement upgrading}

Presently, most developing world governments have diverted their action from clearance to in situ upgrading of informal settlements (Minnery et al., 2013). This shift is associated with eradicating urban poverty (CURE, 2005). Since the informal settlements are playing a crucial role in shaping the urban economy, especially that of the urban informal sectors (Pamuk \& Cavallieri, 1998). However, in terms of upgrading the physical conditions of informal settlements, some opportunities went under-considered.

Financing remains a fundamental limitation in upgrading. Financial institutions are typically limited to provide loans for projects that have the potential to generate profit. Private developers, on the other hand, are also interested in constructing profitable projects. It is evident that in a market economy, needs are fulfilled according to financial ability, not according to urgency (Turner, 1972). The gap between payment and income ratio turn out to be a burden for the poorer. Therefore, they became invisible to this housing finance process (Turner, 1972). The Government of Bangladesh has a separate house-building finance corporation and an allocation for low-income housing in the national budget (UN, 2016). Most of such budget is spent on the infrastructural sector rather than need-based priorities (Harris \& Arku, 2006).

Housing support services, combined with access to housing finance, can provide households with necessary technical and financial information and resources. These are of two types: non-construction and construction. Non-construction support services enable households and communities to access infrastructure and services - a preconstruction phase of incremental development (Bah et al., 2018). Moreover, this incremental process of upgrading requires a long time to be implemented as a policy. In the case of developing countries, political instability does not allow to implement long-term policies. They often get disrupted during the middle of the project when the political Government changes.

In Bangladesh, UNDP's recently completed housing upgrading works (called UPPR - Urban Partnership for Poverty Reduction) identifies several key elements that made upgrading sustainable (Mostafa, 2015). These have been: tenure security; households' active participation in need/priority assessment; designing and construction of houses; households' reuse of previous building materials to compensate for insufficient budget; need-driven efficient and simple design solution of buildings; building layouts that benefit income generation, and creation of seed funds like CHDF (usually under community's ownership). However, this project did not adequately been aligned with the Government's policies, especially at regional and national levels. Not enough was done to engage and influence national policies.

Studies on low-income housing have historically overlooked the role of housing in income generation (Sheng, 1989). Yet, home-based enterprises (HBE) are a critical means of livelihood for a large proportion of the households in these settlements, and any upgrading intervention has the potential to affect their viability. As the prospect of formal employment continues to diminish in many cities, the use of the home as a place for production as well as reproduction rises in importance. Mainly, homes in these settlements are often used for a wide range of income-generating activities such as the running of kiosks and taverns, room renting, food 
production, and other business activities (Mpembamoto et al., 2017). People initiate them as a solution to the unemployment problem and make use of their homes for a range of economic activities.

In informal settlements, a house is a production place, market place, entertainment center, financial institution and also a retreat. The (space of) home provides the ultimate environment for trading off resources between domestic and productive activities (Tipple, 2005). The presence of HBEs contributes to the wellbeing of both neighborhoods and home (Tipple, 2005). Making intelligent use of their dwelling space, the urban poor's home-based activities contribute to their livelihoods (Ghafur, 2001). Many inhabitants opt for home-based works because they cannot afford to find work elsewhere, and he/she does not possess any resources apart from the house that he/she can use for income generation (Hakim, 2014). Nevertheless, HBEs are not mainstreamed in housing upgrading schemes, and neither are their provisioning prioritized in upgrading works whatsoever.

\subsection{Prioritizing needs of the poorest}

In settlement upgrading, officials measure the success/failure of a project in terms of the durability of the structure and its compatibility with officially defined 'standards'. These often do not conform to the affordable/achieved/desired 'standard' by the poor dweller, which are 'not beautiful' and appear incomplete/temporary (for they are built with non-permanent materials). However, such buildings certainly express the informal dwellers' freedom of choice and level of affordability. Sometimes for the poorest among these dwellers, dwelling improvement is not the priority at all. A family with very low income may only ask for a simple tenure-secured place for living, privacy and protection. Low-income dwellers may even opt for investing in house only to secure some income (by renting out or create space for work/shop/cottage industry) and aspire to become permanent homeowners this way (Sheng, 1989).

It is also essential that informal settlement upgrading consider different scale levels of the settlement in question (Minnery et al., 2013; UN Habitat, 2014). From the settlement-city threshold to the smaller household scales are equally important. The latter is of particular importance for it is where individual households' needs, priorities and the question of affordability are asked and negotiated. Upgrading also considers incrementalism and phasing. Some essential questions may include "what are the project components and what level of improvement is to be made and at which level? What is the affordability of improvements for individual households? What standards are adequate and match the affordability of individual dweller?" (UN Habitat, 2014).

\section{METHODOLOGY}

The purpose of this study is to critically examine current practices, problems and reasons of upgrading housing in informal settlements and underscore the real necessities in upgrading by taking account of participants' experience in their natural settings. This research hence used a qualitative methodology (Creswell, 2009), and case study approach for exploring the way of prioritizing of participants' needs in housing upgrading. 
From the literature review and preliminary field observations, it was clear that housing upgrading in informal settlements is more sectoral, and it is primarily the infrastructural development that takes place in the name of housing upgrading. Thus, two such settlements were identified and selected as cases within Khulna City Corporation (KCC) area, where various phase-wise infrastructural upgrading has been taking place with the assistance from different external organizations. The recent statistics indicate that about $19.5 \%$ of the urban population is living in slums and informal settlements, while 538 clusters have been identified all over Khulna city alone (KDA, 2001 as cited in Sikder et al., 2015). Guided by secondary sources, we reached to a common consensus that UNDP has been working in upgrading slum for a long time compared to other organizations, and it has categorized informal settlements (Figure 1) into three categories like extreme poor (39), poor (55) and better off (39) covering most of the informal settlements of KCC. Due to our research focus, we purposively selected two extreme poor settlements (which also allows comparing when required) from the untitled official documents (provided by UNDP staff) during KII these are Montu Colony and Kashipur Bastee respectively.

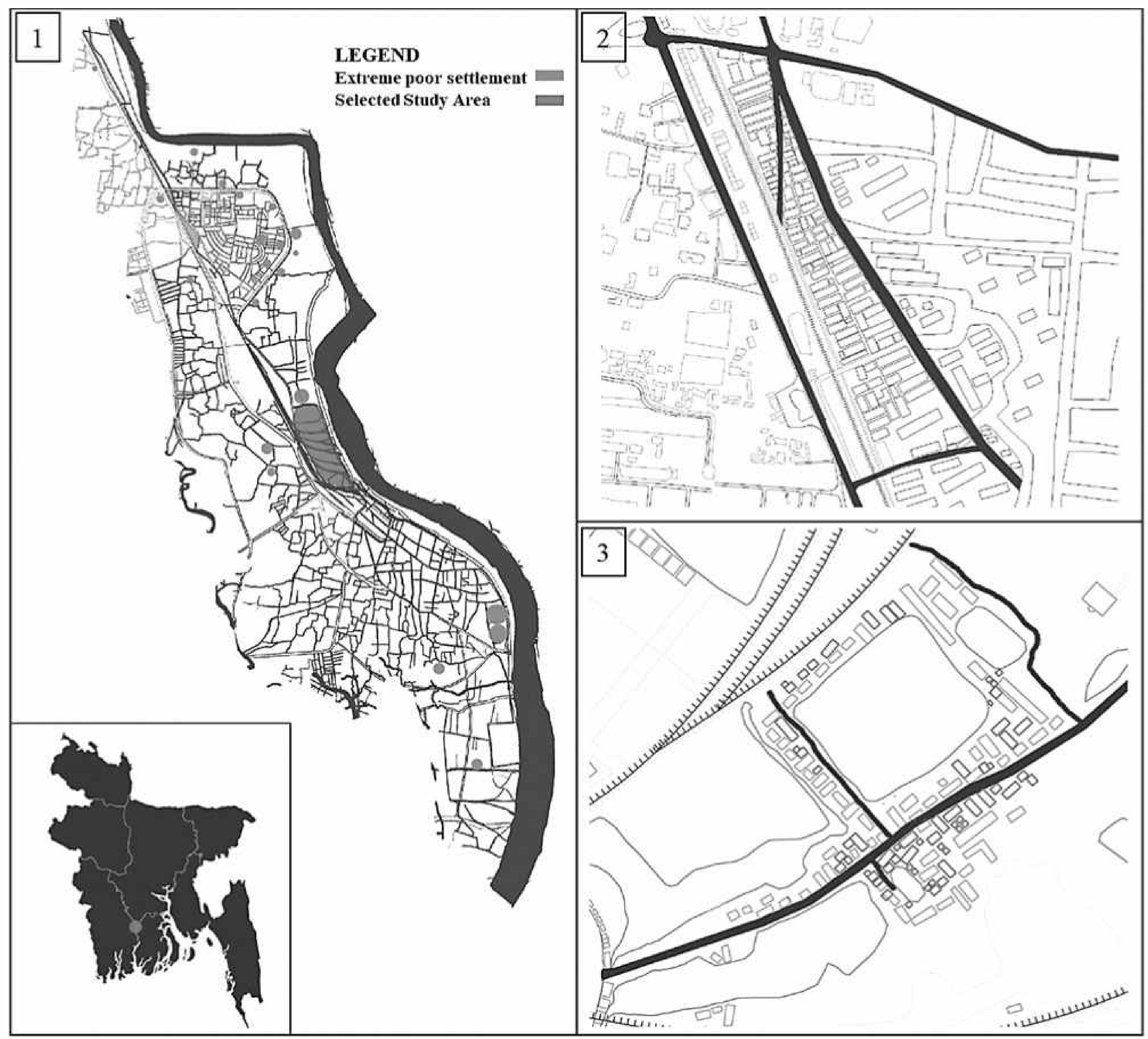

Figure 1: 1) Study settlement locations in Khulna; 2) Kashipur Bastee; 3) Montu Colony Source: UNDP local office, Khulna 
UNDP typically uses the MPI (Multidimensional Poverty Index) ${ }^{1}$ To categorize informal settlements, this is further cross-checked by physical inspection of the settlement in question. At this point, to justify our selection as to informal representative settlement that was categorized as extreme poor within Khulna city, we have used a set of pre-defined criteria determined by relevant literature review. These criteria included land tenure, the density of household, accessibility and connectivity, building types, environmental degradation and significance in terms of population size, location and area (Table 1). After collecting all secondary information available on informal settlement clusters of Khulna city, and conducting a preliminary review of those, we shared this with local experts (UNDP officials). As an outcome, Montu Colony and Kashipur Bastee were found quite relevant for our case study. The two areas are located within the jurisdiction of KCC Wards 21 and 10 respectively.

Table 1: Pre-defined selection criteria and their situation in Montu Colony and Kashipur Bastee

\begin{tabular}{l|l|l}
\hline Pre-defined criteria & Situation in Montu Colony & Situation in Kashipur Bastee \\
\hline $\begin{array}{l}\text { Location: to be on illegally } \\
\text { occupied public land. }\end{array}$ & $\begin{array}{l}\text { Land belongs to the Bangladesh Railway } \\
\text { and it is illegally occupied. }\end{array}$ & $\begin{array}{l}\text { Land belongs to the Bangladesh } \\
\text { Railway and it is illegally occupied. }\end{array}$ \\
\hline $\begin{array}{l}\text { Overall profile: population } \\
\text { size, location, total area } \\
\text { compared to others. }\end{array}$ & $\begin{array}{l}\text { 365 households, high land price and } \\
\text { densely populated. }\end{array}$ & $\begin{array}{l}\text { 420 households, high land price and } \\
\text { densely populated. }\end{array}$ \\
\hline - $\begin{array}{l}\text { Connectivity: with public } \\
\text { services and networks. }\end{array}$ & $\begin{array}{l}\text { Poor connectivity with main road and thus } \\
\text { the dwellers fail to access municipal } \\
\text { services adequately. }\end{array}$ & $\begin{array}{l}\text { Poor connectivity with main road and } \\
\text { thus the dwellers fail to access } \\
\text { municipal services adequately. }\end{array}$ \\
\hline $\begin{array}{l}\text { Building types: in terms of } \\
\text { durability. }\end{array}$ & $\begin{array}{l}\text { The building type of this settlement is } \\
\text { semi pucca } \text { and } \text { katcha mostly. } 97 \% \text { is of } \\
\text { total household is katcha } \text { and semi pucca. }\end{array}$ & $\begin{array}{l}\text { More than } \text { 92\% of the total household } \\
\text { is katcha } \text { and semi pucca. }\end{array}$ \\
\hline - $\begin{array}{l}\text { Environmental } \\
\text { degradation. }\end{array}$ & $\begin{array}{l}\text { Due to mismanagement of drainage } \\
\text { system waterlogging remains in every } \\
\text { rainy season. }\end{array}$ & $\begin{array}{l}\text { Lack of proper managing of drainage } \\
\text { system, waterlogging is almost } \\
\text { permanent. }\end{array}$ \\
\hline
\end{tabular}

It is important to gain access to research sites by seeking the approval of gatekeepers individuals at the research site that provide access to the site and permits the research (Creswell, 2009). Since UNDP's local office at Khulna has been working in these settlements for infrastructural development for more than a decade, their network of informants (mostly female 'gatekeepers') has been used for accessing these settlements to take photographs, collecting information and identifying issues prevailing in these settlements. In order to collect data, we used multiple methods such as observations, interviews, audiovisual materials and documents as got from UNDP officials regarding settlements and the dwellers relating to their housing like the electric bill, national Id and Xerox copy of the submitted application to a local political leader or the office of the local council for confirmation tenure security in various times. A single program (a within-site study) like 'the way of selecting participants' priority' has been used. Within these two settlements, several individuals (due to time and money constraints ten females from each site who are not capable of paying back) purposefully selected as respondents.

1. MPI includes nutrition, child mortality, total year of schooling, school attendance, cooking fuel, sanitation, drinking water, electricity, housing and assets (Santos and Alkire, 2011). 
Table 2: Data collection Framework

\begin{tabular}{|c|c|c|c|}
\hline Method & Source/respondents & Quantity & Field of data/information \\
\hline \multirow[t]{2}{*}{$\begin{array}{l}\text { KII (Key } \\
\text { Informant } \\
\text { Interview) }\end{array}$} & $\begin{array}{l}\text { Coordinator of present } \\
\text { housing upgrading } \\
\text { program of UNDP }\end{array}$ & \multirow{2}{*}{$\begin{array}{l}02 \text { from } \\
\text { each } \\
\text { settlement }\end{array}$} & $\begin{array}{l}\text { Informal settlement interventions by KCC; getting } \\
\text { its assistance to access selected settlements. }\end{array}$ \\
\hline & $\begin{array}{l}\text { CDC (Community } \\
\text { Development } \\
\text { Committee) leader }\end{array}$ & & $\begin{array}{l}\text { History of settlements, land occupancy, civic } \\
\text { services, tenure security, and livelihood dimension } \\
\text { of community and facts of selected respondents, } \\
\text { history of upgrading, history of upgrading. }\end{array}$ \\
\hline $\begin{array}{l}\text { - Non } \\
\text { participant } \\
\text { observation }\end{array}$ & $\begin{array}{l}\text { Selected dwellers from } \\
\text { two Settlements }\end{array}$ & $\begin{array}{l}\text { All over } \\
\text { settlement } \\
10 \text { from } \\
\text { each } \\
\text { settlement }\end{array}$ & $\begin{array}{l}\text { Settlement infrastructure, structural condition of } \\
\text { dwelling units, history of upgrading. } \\
\text { Respondents' origin, socio-economic condition, } \\
\text { occupancy, movement, income and expenditure, sets } \\
\text { of priorities, history of upgrading. }\end{array}$ \\
\hline $\begin{array}{l}\text { Document } \\
\text { analysis }\end{array}$ & $\begin{array}{l}\text { Provided by UNDP } \\
\text { office and settlers }\end{array}$ & N/A & $\begin{array}{l}\text { Settlement list; legal documents like electric bill, } \\
\text { national ID and copy of submitted application for } \\
\text { occupancy, history of upgrading. }\end{array}$ \\
\hline
\end{tabular}

During fieldwork, we observed respondent's daily routine, took notes of those, and sketched and photographed their living spaces. Unstructured interviews with the participants were also conducted using thematic questions. Interviews were recorded (and further transcribed), and photographs were taken with the permission of the dwellers. To obtain or cross-check facts about the participants' extreme poor status, their neighbors, workmates, and gatekeepers were also interviewed. (Table 2) further details out this.

To analyze data, we followed a thematic analysis of a specific aspect of the case. A detailed description of these two cases has emerged in which we described detailed aspects such as settlement's history and dwellers' livelihood. Following this description, we have focused on a few key issues through thematic analysis. Our primary intension was not to generalize beyond the case, but rather to understand the complexity of the case.

\section{THEMATIC DISCUSSION OF THE CASE}

\subsection{Settlement profile}

The settlement called Montu Colony is located in the southern part of Khulna city. It is privately owned, where the dwellers have erected their houses on a piece of land, owned through a 99-year leasehold by Mr. Montu Mia orally from railway authority in 1971 of what found no formal paper because 'Montu Mia' has expired. Present dwellers have an only paper of electricity bill. In recent years, the colony dwellers began to realize the importance of a permanent tenure of this settlement as the railway authority began denying this ownership arrangement. In this sense, none of these dwellers' tenure is secured. From primary inquiry, we observed that those who claim to be the landowners are purchasers of right from previous owners. In turn, the land continued to get occupied by one after another but none with any legal ownership whatsoever. The other settlement is called Kashipur Batsee located in the northern of KCC area, is built illegally on a narrow strip of Bangladesh Railway's land, and in the shadow of a line of shops facing the Dhaka-Khulna national highway. None of these two settlements has tenure security. They also share some common attributes as in the following. 
365 and 420 households are presently living in almost 50-year-old Montu Colony, and Kashipur Bastee respectively is a very dense area. Their gross income level ranges from Tk. 5,000-10,000/household, while the average household size is 4-5 persons/house in both settlements. On the other hand, in Kashipur Bastee, $30 \%$ of the households have an income level more than Tk. $10,000 /$ month, while $55 \%$ have an income ranging from Tk. 7,000-10,000/month. Around $15 \%$ of households there has their income less than Tk. 7,000/month. In both settlements. This tells us that the average per capita living expense of both settlements lies well below the national poverty line, which was $\$ 1.90$ (Tk. 160) in 2019 (ADB, 2019). Most dwellers here work as rickshaw pullers, day labourers, hawkers, shopkeepers and auto drivers. The female members are mostly housewives, while the rest (nearly one third) work as housemaids in nearby residential areas. The average earner and dependent ratio of Kashipur Bastee is $23 \%$ and $77 \%$, and Montu Colony is $56 \%$ and $44 \%$. Most dwellers here spend their earnings in non-housing consumption, such as buying food, electricity bills, schooling and medical expenses, transport, clothing and fuel.

\subsection{History of physical upgrading in the elected informal settlements}

There have been ongoing efforts from both $\mathrm{KCC}$ and NGOs/donors in the physical upgrading of informal settlements in Khulna, which began in the 1990s and continued well into the 2000s. A key objective of these efforts was to compensate for the missing essential services and infrastructures and hence help these apparent 'slums' to attain the stature of 'housing'. However, in the actual upgrading works, instead of focusing on the dwelling level, priority was mostly given to community- and settlement-level interventions. We found that most of these works had sectoral focus, rather than being comprehensive and often carried out in an uncoordinated manner. There were cases of repetitions (e.g. same work done by different NGOs), non-prioritized construction (e.g. construction of community facilities when people needed livelihood supports) etc. Works included the construction of internal roads, paving, drains, community toilets and tube well provisioning etc. Table 3 provides a summary of this.

Table 3: Efforts in physical upgrading of housing in Kashipur Bastee and Montu Colony.

\begin{tabular}{|c|c|c|c|c|c|c|}
\hline Facilities & Toilet & Tube well & $\begin{array}{l}\text { Infrastructure } \\
\text { (drain, roads) }\end{array}$ & $\begin{array}{l}\text { Homestead based } \\
\text { loans }\end{array}$ & $\begin{array}{l}\text { Elementary } \\
\text { and Primary } \\
\text { School }\end{array}$ & $\begin{array}{l}\text { Child Friendly } \\
\text { Learning and } \\
\text { Recreation } \\
\text { Center }\end{array}$ \\
\hline $\begin{array}{l}\text { Montu } \\
\text { Colony }\end{array}$ & $\begin{array}{l}\text { Habitat for } \\
\text { Humanity } \\
(2016) \\
\text { Nobolok and } \\
\text { Water Aid } \\
(2010,2013 \text {, } \\
2016)\end{array}$ & $\begin{array}{l}\text { BRAC (2019) } \\
\text { Nobolok and } \\
\text { WaterAid (2010, } \\
2013,2016)\end{array}$ & $\begin{array}{l}\text { UNDP (2017) } \\
\text { KCC (2015) }\end{array}$ & $\begin{array}{l}\text { BRAC (2014-) } \\
\text { ASHA (2010-) } \\
\text { UNDP (2015) }\end{array}$ & $\begin{array}{l}\text { Primary } \\
\text { Education } \\
\text { Ministry, GoB } \\
\text { (2015) }\end{array}$ & $\begin{array}{l}\text { World Vision } \\
\text { (2016) }\end{array}$ \\
\hline $\begin{array}{l}\text { Kashipur } \\
\text { Bastee }\end{array}$ & $\begin{array}{l}\text { UNDP (2011, } \\
\text { 2019) }\end{array}$ & $\begin{array}{l}\text { KCC (2007) } \\
\operatorname{UNDP~(2011)~}\end{array}$ & $\begin{array}{l}\text { UNDP (2009) } \\
\text { KCC (2013) }\end{array}$ & $\begin{array}{l}\text { BRAC (2015) } \\
\text { ASHA (2010-) } \\
\text { UNDP (2015) }\end{array}$ & BRAC (2016) & $\begin{array}{l}\text { ASHA } \\
(2016-2017)\end{array}$ \\
\hline
\end{tabular}

Most of these projects' focus was governed by implementing organizations' priority sectors and budget spending limits, project completion deadlines and dwellers' ability to paying back etc. NGOs provided loans to individuals to improve the housing conditions of the poor, but when 
actual selection took place, it was marred by favoritism and biases. As a result, the poorest of the poor families have always been overlooked and left unselected. Salma, a dweller from Montu Colony and a single mother with two children wondered,

"What's the use of all these surveys and listings? I have nobody to look after me. I have the worst condition in this settlement but I am still not listed (for aid). Ultimately, the people who have more will get more. We are not of importance to the leader; so, no aid would reach us".

For having the lowest socio-economic status even within this poor community and without any command and control over their decisions, the poorest among the poor are the worst vulnerable (single mother, physically challenged, elderly having a single source of income) and usually suffer the most. The elderly widowed woman named Ayesha from Kashipur Bastee often lives from the sympathy of her neighbors. All of these neighbors, who are also very poor themselves, feed her a meal or two every other day to save her from starving. Ayesha does not have any other earning member in her family and lives on her own. She tells us,

"I don't avail any government grants or any support (e.g. from social safety net); all I need at this age is a source to feed myself at least..."

Above instances show that there is a grave need of focusing on the household level to support the extreme poor. During interviews, as we came to learn about their exclusion, we got curious whether at all they would like to upgrade their houses and what would be its preferred extent? Respondents replied that they cared less about their dwellings rather more about their income/livelihood chances. Indeed, toilets, drains and tube wells were necessary, but for the extreme poor, a regular income and availability of job and food were even more important than what the NGOs, Donors and KCC thought. The conventional indicators used by external organizations did not help identify what (and whether) the poorest among these peoples' actual dwelling-level needs were. The livelihood dimensions of the poorest people, with no regular income and earning member, lack of personal property and savings, income-expenditure gap, un(or under)used human capital and potentials of household spaces were often grossly missed while preparing the priority lists for housing upgrading externally. Often those who are more connected, influential and had more power, suppressed their voices.

For the poorest dwellers, non-housing expenditure always proves more important for sustaining life; hence it is prioritized compared to housing expenditure. About $90 \%$ of their little income is spent on catering for non-housing needs. Therefore, they are typically left with almost nothing to spend on the dwelling unit. Here the priority of these poorest families is a secured and stable income source. Without this, a house or housing expenses is burdensome. This does not allow them to save anything as well. It is due to this the extreme poor family does not risk-taking credit/borrowing and upgrade their house. This is further compounded by their lack of permanent or secure tenure. Without tenure, most dwellers are not even considered for any credit from the public nor the NGOs. Interview with local NUPRP officials revealed that there are still no criteria in place to figure out how and for what purpose the poorest amongst the informal settlement dwellers will be able to avail the loan and pay it back. Elsewhere in Khulna, BRAC's (2020) ongoing dwelling improvement projects in informal settlements show that dwelling improvement credit is made available to people only who are capable of paying back the monthly instalments. 
Almost no one among the dwellers is permanent job holders, who work in the formal sector, while most of them are not covered by any social safety net provided by the Government. People work mostly daily and work for about 15-20 days a month and have a very high dependency rate (77\%). Around $66 \%$ of families have a single earner (with non-working female members), while there are $2 \%$ of families who have physically challenged and ailing people as their family members. Moreover, just like rural times, poor dwellers' income is also heavily affected by seasonality. For the poorest, supplementary income remains the priority.

Moreover, they have substantial social capital, but in individual development, this capital does not work because, in extreme poor settlements like these, the same economic condition typifies almost everyone. A potential yet idle workforce is also to be found in these settlements; a good number of non-working housewives and youth (around 75\%) have expressed their willingness to participate in possible income-generating activities since they are currently jobless. We identified that women tend to have some skills like paper-packet making, cooking, sewing and cattle farming etc. However, it is mostly due to the lack of start-up capital, further skill training, and a lack of income-generating space in their dwelling that their human capital remains underutilized. $40 \%$ of households possess very little in-house space, while many female members stay home as caregivers of their children or physically disabled/ailing family members. Due to religious reasons, some husbands do not allow these women to travel outside and work. Therefore, in order to prioritize poorest peoples' needs in physical upgrading, it appears essential that policy discourses consider both social (capital and space) and economic (labor force, human capital) dimensions of livelihoods.

\subsection{Constraints in setting priorities for physical upgrading at dwelling level}

This section reports the key challenges and issues that impede priority setting for housing upgrading in the studied settlements. Four interrelated issues, namely: lack of tenure security, prolonged exposure to natural disasters, very high renter-owner ratio, absence of non-monetary livelihood dimensions and missing HBE dimensions are identified as the key constraints in housing upgrading in these two settlements.

\subsubsection{Lack of negotiation for tenure security}

Both the studied settlements lack tenure security, and it is only about a decade ago that this refrained local governments and other organizations from housing/settlement upgrading. However, it was about a decade ago, that fueled by global upgrading drives, the UNDP-led UPPR project began its operation here. However, despite investing/improving in sectors highlighted in (Table 3) and lobbying with the landowner (Bangladesh Railway) from UNDP, their tenure could not be secured. Other NGOs/donors, of course, did not do much in terms of lobbying. It is then dwellers stopped, even considering investing in dwelling improvements with a persistent fear of eviction. The so-called landlords (even if they are not the legal owners) told us that they pursued local politicians and KCC officials to warrant tenure security, but nothing could have been achieved since in both cases the land is owned by Bangladesh Railway. Hence, the dwellers fear eviction and refrain from investing in housing upgrading. Recently, at Kashipur Bastee, dwellers even had to forfeit $15^{\prime}$ of land on either side of the present railway track to give way to its forthcoming widening works. Many dwellers lost portions of their houses by this. 
Despite all houses in this settlement had their holding numbers put, and got electricity connections with a meter, these little hints of formality could not warrant land tenure security. The key weakness in tenure negotiation was the complexity of land for being the government property and also the weakness of dwellers to convince the Government. Dwellers feel that without tenure security, they do not have much chance to avail civic facilities and improve their present economic condition. Therefore, tenure security appears to be an essential precondition for identifying dwelling level priorities.

\subsubsection{Prolonged exposure to natural disasters}

A severe lack of utility and service infrastructure made the spatial environment nearly unlivable and prone to waterlogging and chronic waterborne diseases. Especially in rainy seasons, these people suffer from waterlogging. Despite a drain provided by UNDP, waterlogging persists as household wastes are disposed of there. About $85 \%$ of the houses here have katcha/mud plinth, and Katcha houses are usually the most severely affected during rainy seasons by being inundated and washed out for a long time. Hence, all these houses require more significant maintenance and yearly investments. Although NGOs and donors have carried out various sectoral upgrading works at the settlement-level, problems of seasonal waterlogging persist. This prolonged and unresolved waterlogged situation and associated maintenance cost also discourage them from upgrading their houses, although they feel there is a serious need of upgrading at least the building plinth. Almost $95 \%$ of households - both tenants and owners, could afford to spend very little in maintenance and that is not more than $10 \%-15 \%$ of their income.

\subsubsection{High renter-owner ratio}

Most families here are long-term renters. At Montu Colony, the renter to owner ratio is 70:30, while it is around 75:25 at Kashipur Bastee. Due to cheap rent (ranging from 6 to $8 \mathrm{BDT} / \mathrm{sqft}$ ) and workplace proximity, these people prefer living here despite all its infrastructural deficiencies. Among these a few can afford to live elsewhere (even as tenants). Therefore, the renters here, who are also the majority, are naturally reluctant about eviction, and they depend on their so-called landlords for repairing/maintaining the houses. Moreover, even if many have been living in these settlements for almost 50 years, they still consider themselves as renters who are just about content to be able to stay here at such a low cost without raising their voice in issues otherwise. For one-tenth owners, renting out rooms is the only income source. However, renting out in such cheap rate does not allow them to save adequately and hence invest in housing improvement or afford a loan for that.

\subsubsection{Absence of non-monetary livelihood dimensions}

Different livelihood aspects (especially the social and economic dimensions) are rarely considered in need assessment and prioritizing physical upgrading for the poorest. Various NGOs provide infrastructures as part of overall housing/settlement upgrading scheme; after which, they just leave. There is not much history of investment can be found in provisioning community-level gathering spaces or upgrading children's play areas. For example, the dwellers of Kashipur Bastee complained that no funding was ever channelized to improve neighborhood or community spaces where they could gather and spend time together, which may also be used 
flexibly for income generation (e.g. street business and supplement scarce in-house space). Yet in both settlements, dwellers have kept transforming the very scant spaces (the house itself and adjacent streets) into intense multi-activity spaces by performing almost all household and social activities (private, semi-private, and public) there. Service areas like 'kolpar' (water collection cum bathing points at the location of tube wells), neighbors' veranda, and street corners are all used as social gathering spaces (Figure 2) that boost social networking and social capital. Such socio-spatial dynamics point to an intricate social network that triggers spontaneous group response and helps sustain the poorest, especially in moments of crisis.

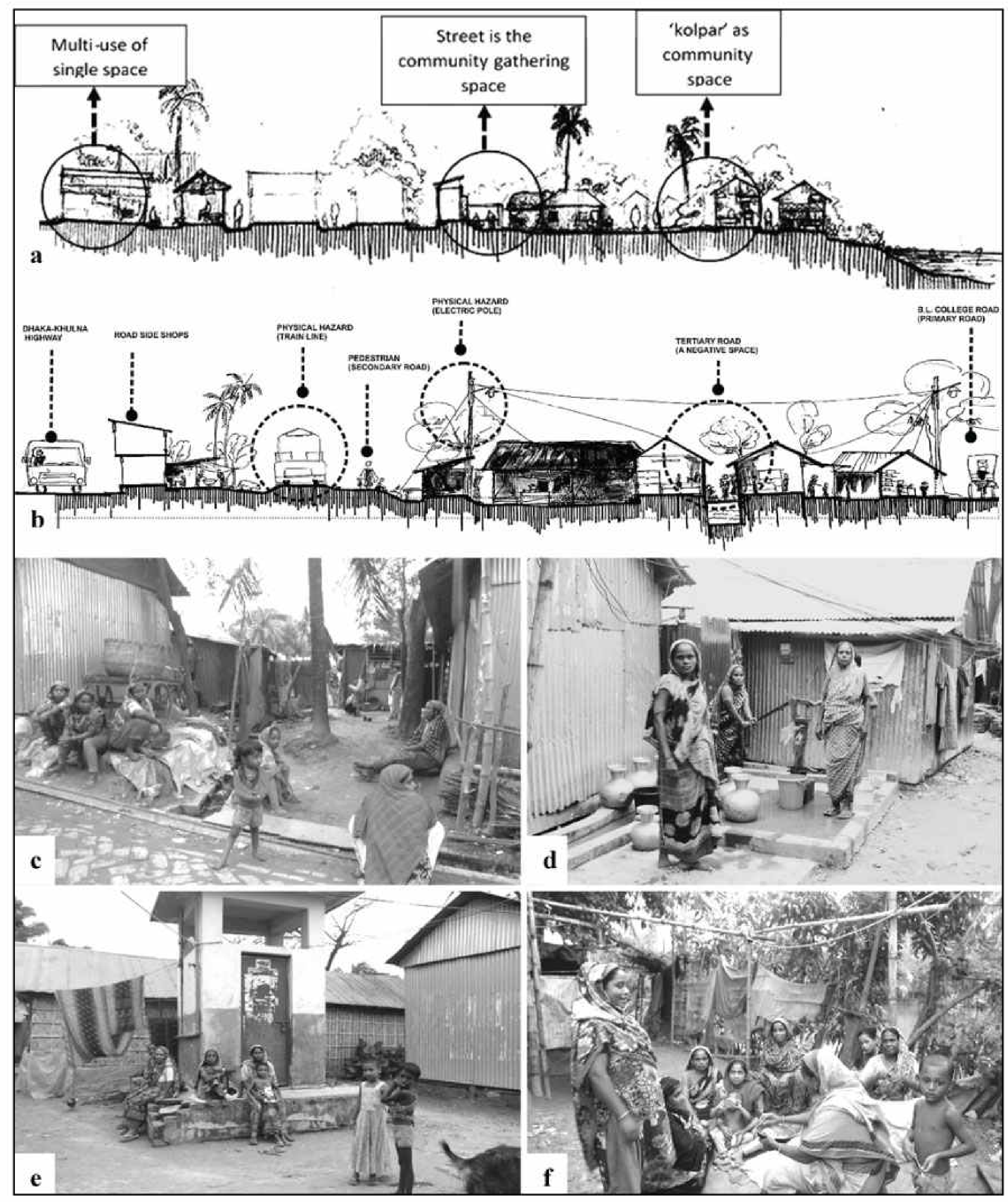

Figure 2: a) Longitudinal section showing neighborhood-level community space; b) Traverse section showing potential social gathering spaces as well as negative spaces through the informal settlement c) \& f) street-side common entrance to houses and space between two houses acting as social gathering platform d) kolpar being the social interaction point e) social gathering beside toilet. 


\subsubsection{Missing $\mathrm{HBE}$ dimensions}

Although a good number of upgrading initiatives aimed to improve both spatio-physical and socio-economic conditions of informal settlements and their dwellers, these works were not founded on poor people's capabilities and ongoing practices. There is also a tendency among these dwellers to pursue home-based income generation activities; in both settlements, at least $33 \%$ of the households have been found who are involved in some sort of HBE activities such as renting, running small groceries, selling fire-woods, vegetables and snacks, rearing poultry or cattle, tailoring and making products. For some dwellers with greater financial difficulty, provisioning of some sort of in-house income generation space was felt more important than actually owning a 'house'.

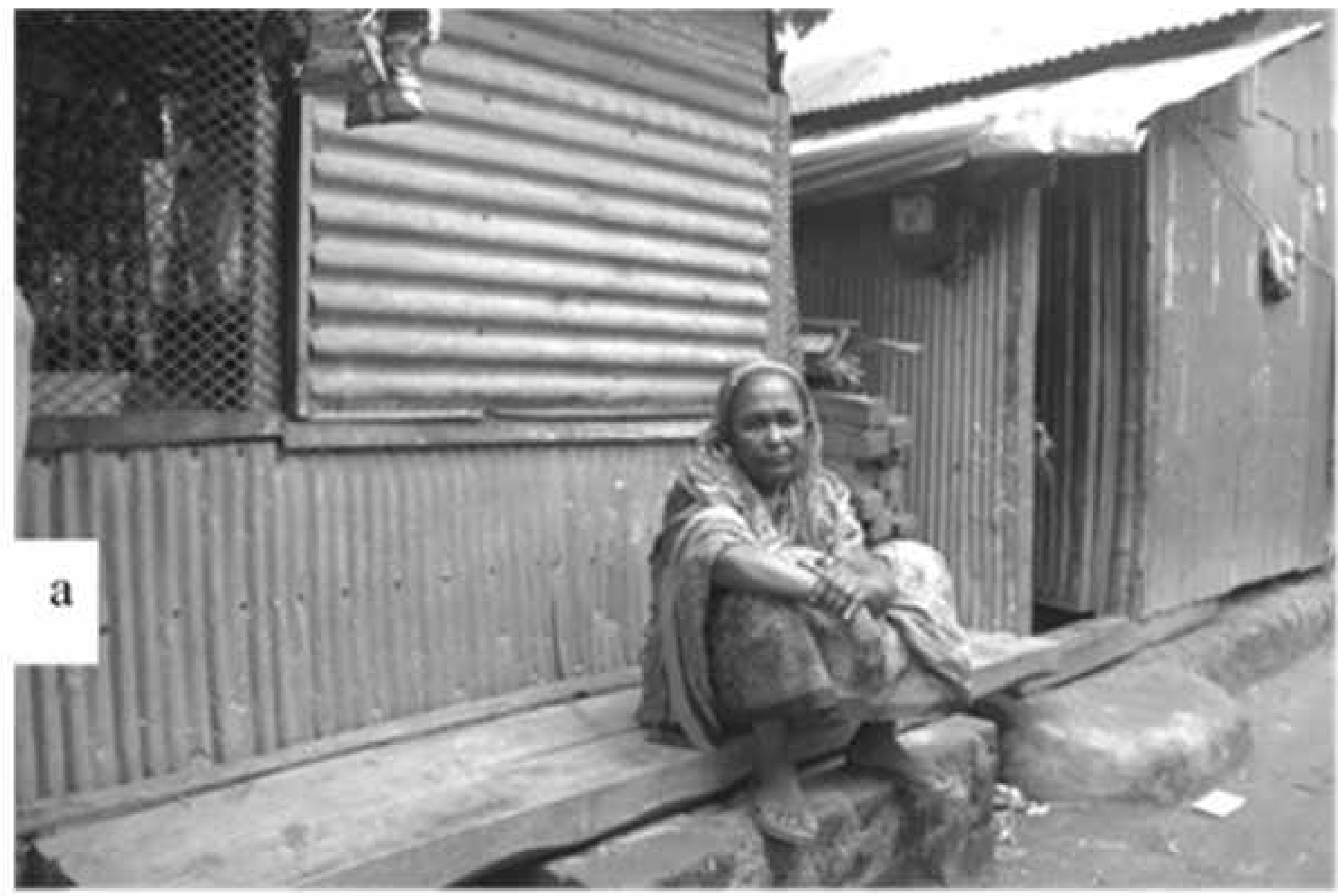

Figure 3: a) window shop; b) veranda as shop

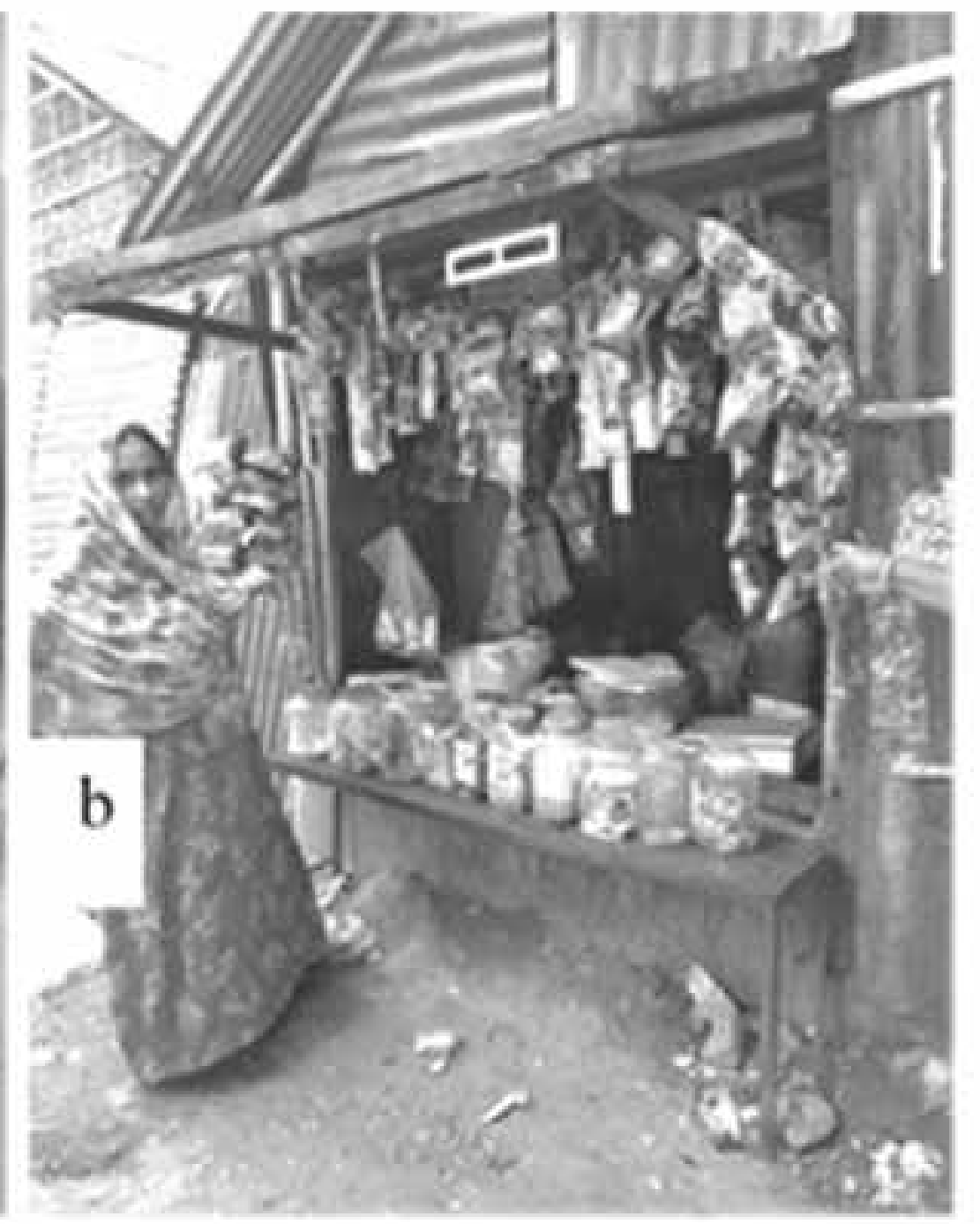
.

Although credit facilities for doing business are plenty through numerous micro-credit schemes offered by various NGOs, minimal credit facilities are available in helping to create new income-generating spaces or modify existing ones. Due to a severe dearth of household spaces, people were forced to adopt multiple uses of in-house spaces - often compromising the very basic need of privacy, especially for the women. In Kashipur Bastee, Sufia Begum opened a window shop using her only bedroom (Figure 3a), keeping goods on her window-side bed and hanging grocery packets from her window's wooden panels. She stores her business goods in a false wooden ceiling, hung high above within the gable space of her house, to protect those from flooding. In some cases, the veranda spaces prove to be the most useful due to its flexibility and openness. Abdul Barek from Montu Colony is a shopkeeper who uses his road-adjacent veranda as a shop (Figure $3 b$ ). Years ago, during rainy seasons, this shop used to inundate, and most of the goods got spoiled. Afterwards, he invested in raising the plinth height of the veranda, safeguarding his goods and hence buffering from financial loss.

However, for most houses being Katcha and semi-permanent and hence prone to rains and winter, they could be only partially used - making a constant flow of production/income almost impossible. For the tenants, it gets even more challenging to carve out some space of their already very scant rented room for economic production. In the absence of adequate indoor spaces for HBE, provisioning of public infrastructures such as paved roads, community centers and schools, or even drain covers are essential livelihood boosting facilities that contribute 
positively to their income generation. From the respondents' income generation activities, we found that without a paved surface and in a waterlogged scenario, income drops significantly.

\subsection{Physical upgrading priorities for the benefit of extreme poor dwellers}

Based on the findings reported earlier, the following upgrading priorities can be made.

\subsubsection{Continued physical upgrading at settlement level}

Despite its criticisms and even though problems persist, physical upgrading initiatives have been contributing to the improvements in the overall environment of these settlements. Unfortunately, most of the time, these sectoral developments are not being sustainable, and people are also not aware of physical upgrading. Rather income-generating and livelihood prospects are their primary concern. Before upgrading, alongside their waterlogged condition, dwellers' health and waterborne diseases were also acute as the dwellers said. Each year, waterlogging would also destroy Katcha plinths of almost every house of these impoverished settlements. When new drains were provided, internal paved roads were constructed, and plinth heights of some houses were elevated, problems regarding inundation, health and waterborne diseases were resolved to a good extent. The provisioning of deep tube wells, although inadequate in number, later took care of the drinking water problem to some extent. It was also found that households that could afford to construct an upper/mezzanine floor or storage within the house enjoy the availability of more space on the ground floor and thus ensure better profit from their businesses. However, the extreme poor still suffer from waterlogging as they could not raise their plinths to an explicit level. Though the internal drains which were built are connected to the urban drainage network because of dumping all solid wastes into the drains and mismanagement caused acute waterlogging during the rainy season.

\subsubsection{Tenure security}

People with unsettled tenure status remain the most vulnerable. Especially in present times when most informal settlements have their tenure secured through the joint efforts of KCC and UNDP, it is the floating and people without tenure security are the most vulnerable. Neither they have any political voice and bargaining power since they are the poorest, nor they have any financial resource or assets to compensate for this. Due to this lack of legality and very lengthy negotiation needs, NGOs and development organizations do not include these settlements in their priority list for more in-depth interventions (like a dwelling). Working out tenure security for the extreme poor settlements must be ensured for setting city-level priorities for housing upgrading, and bring about positive change in the lives of the poorest.

\subsubsection{Right beneficiary selection}

The overwhelming presence of donor agencies and NGOs offering various credit schemes and subsidies toward infrastructure and house-improvement (upcoming), prompting the need for selecting the right beneficiaries. Fairness in the selection process, however, was often questioned due to the partial roles played by the community. In recent times, many of UPPR's CDC leaders were also accused of favoritism and partiality, where in many cases they extended undue favors in selecting right beneficiaries, i.e. the neediest and poorest. In most cases, these beneficiaries include people who are leaders' relatives, compatriots, political party cadre and people from their 
leaders' social network. Favoritism as such took place more when donors and NGOs made donations or highly subsidized loans available. The wrong selection hence probably explains why the poorest continue to remain so despite the availability of financial and infrastructural aids.

\subsubsection{Peoples' capacities and practices}

In order to help the 'poorest of the poor' with housing loans, it is essential to first learn about and then understand their actual needs, and also of their capacity to carry the liability of a loan in the long run. Some cases were reported in these two settlements where people had to sell off the possession rights of their informal settlement house, and flee the settlement or change address to avoid the liability of monthly instalments of NGOs loans. In other occasions, many of these people could not always adapt to their new house, and in times of need, sold off their building materials including CI roof (called tin locally), doors or even bricks out of their walls. People who need food, or who want to get their children educated, with their very scant or almost no resources will surely rank food and children's education above the shelter. The poorest will therefore aim to secure whatever savings they may by instead living in a dilapidated house.

\subsubsection{Non-housing needs}

A large number of the study population were found to have asymmetric needs and interests many of which do not pertain to housing directly. Some households needed an income solution, some needed educational aid, and some needed ideas on starting a business while others asked for introducing a stronger social safety net. In many instances, people asked for skill development training and showed interest in the ideas, information and knowledge about a better livelihood. These supports for non-housing needs could help improve their livelihoods, and people then will take initiatives to transform their mere shelters into better homes. It was observed that people who could improve their livelihood had the better physical condition of their houses (Figure 4).
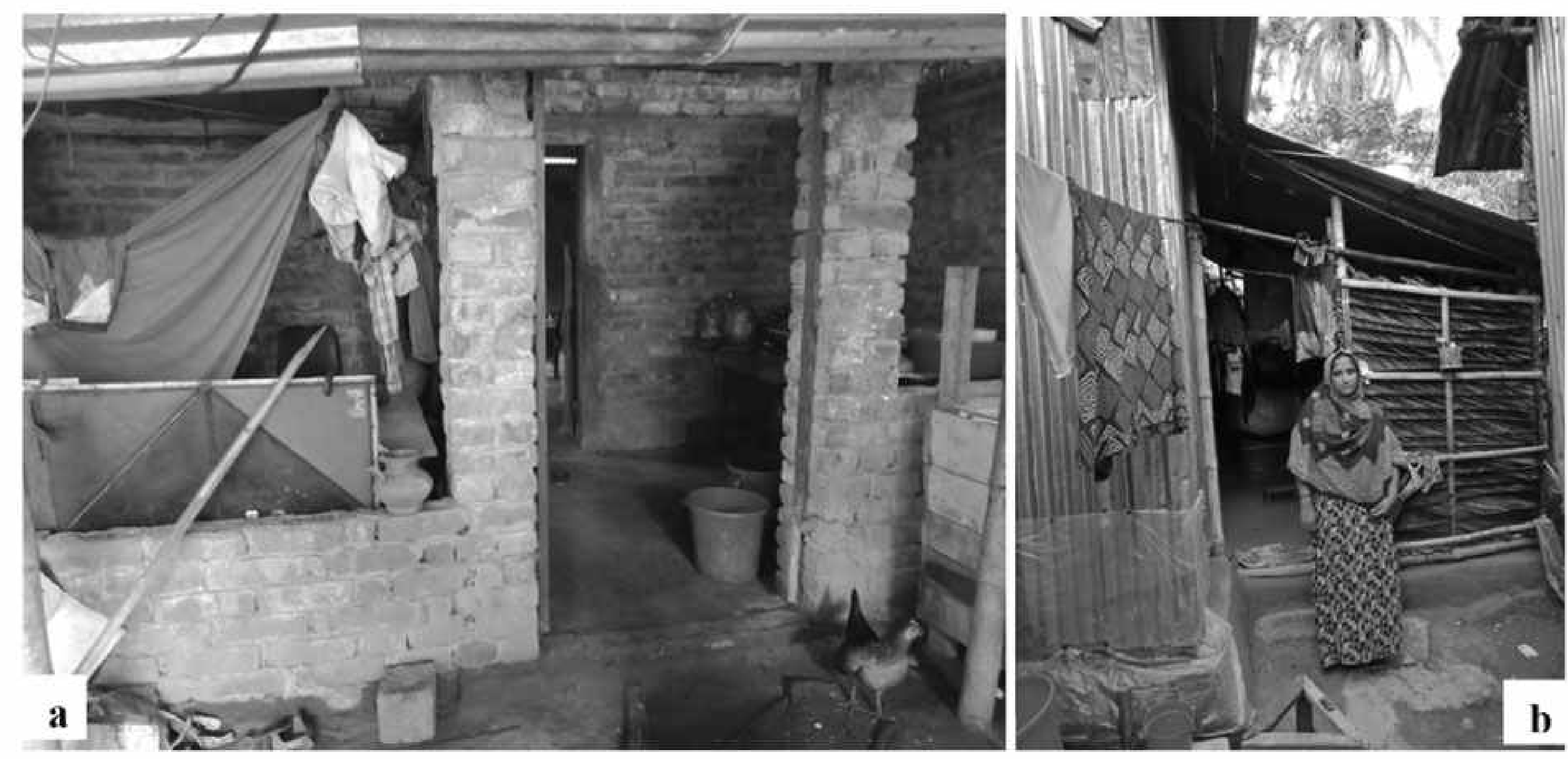

Figure 4: a) Upgradation with a new brick wall; b) Extension of kitchen and installation of new tin. 


\subsubsection{Everyday technical support}

During the last decade, UNDP has been providing technical support (and advice) to informal settlements as part of their CHDF protocol. Many other NGOs (like what BRAC is providing to other informal settlements in Khulna region presently) are also doing the similar. However, all of them provide technical support only during the provisioning of mass housing or other non-household infrastructures like toilets or roads, with big budgetary arrangements. However, instead of occasional and selective supports like these, a regular advice and support/consultancy system from experts and technical personnel on, for example, how to build better, how to avail economical building materials/construction techniques, or access housing credit etc. should help the marginalized people better manage and direct their very little resources. Often, little technical support in fixing or extending a house in the right direction proves much effective than constructing an entire new house.

\subsubsection{Component-wise small/incremental upgrading}

Housing upgrading, when supported by NGOs and donors, should take account of variable income levels, needs and affordability of the dwellers, and hence should be carried out incrementally. With smaller technical assistances, financial arrangements should also support component-wise upgrading and help smaller and incisive interventions like elevating the plinth and making it erosion-resistant, carving out a space for business or retrofitting portions of the roof to be used as storage or promote urban agriculture. A component-wise upgrading as above hence can be the most immediately needed housing component for the poorest when the remaining of the grant/loan might be used for other non-housing needs or supplementing livelihoods.

\subsubsection{Housing and dwelling unit as key livelihood instruments}

When governments and NGOs conceptualize upgrading, house and housing are typically viewed as mere end products, and their productive role is seldom accounted. It is never enough to articulate housing problems in terms of material deficiencies only. Houses or dwelling units, and support services and infrastructure - all of these need to be associated with poor dwellers' livelihoods and other income improvement and social empowerment/enablement programs. To be used as tools for impactful upgrading, housing needs are to be expressed in terms of their priorities. This needs to be integrated with livelihood outcomes; the livelihood implications of housing have never been part of the mainstream discourse in housing literature. In these two settlements, almost every household with a comparatively better living condition has some integrated home-based income generation activities such as - paper-packet making, tailoring or sewing, chotpoti or snacks making, fuelwood storing and selling etc. Altogether, housing in general and houses, in particular, should not be composed of mere inhabitation infrastructure. They should be viewed as strategic livelihood-boosting instruments, which should be incremental, flexible and maybe even unbuilt - to be subject to the poor dweller's needs, priorities and interpretations.

\section{DISCUSSION AND CONCLUSION}

From the above findings, it is clear that settlement level upgrading intensified during the past decade. A good number of infrastructures were also provisioned in the areas of water supply, 
drainage, road construction, and schools and community facilities. Furthermore, all these have improved certain aspects of people's livelihood indirectly and also the overall environmental quality. However, none of these could resolve problems at the dwelling/household-level, and especially in areas of these poor dwellers' income and livelihoods - making dwelling investment/borrowing impossible for them and leaving dwelling units at a dismal status. No actual intervention prioritized the dwelling unit with the goal to improving extreme poor's livelihoods. Key constraints associated with this were the lack of tenure security making the donors and NGOs uninterested, chronic exposure to natural hazards making investments risky, high renter-owner ratio with non-investing renters, donors and NGOs not making investments in non-monetary livelihood dimensions, and missing HBE components in overall housing credit schemes. Issues regarding beneficiary selection, appreciation of poorest peoples' capacities and practices, prioritizing non-housing needs, absence of incremental upgrading schemes and housing not being considered as crucial livelihood instrument also compounded the matter.

Indeed, non-dwelling infrastructure plays a role in upgrading. However, to what extent does it contribute to upgrading peoples' livelihoods directly and undertake their priority needs? The infrastructure projects have widely been adopted at the settlement level, but their success in securing one's income and sustaining livelihoods was seldom measured. Acute poverty still prevails in these settlements despite these infrastructures being provided for many decades. Also, no particular housing finance scheme, maybe subsidized or supported by Government, for these extreme poor communities was reported, although UNDP informed about a forthcoming one. Therefore, we are skeptical that a homogenous scheme, which does not differentiate between poor and extreme poor's needs, priorities and capabilities, will not be able to reduce poverty. World Bank's idea of 'bankable' slums hence becomes questionable as it shows its inclination to neoliberal and market-driven principles, resembling the Anglo-American model that is based on state withdrawal and privatization simultaneously. It is precisely at this juncture that the poorest people's everyday needs are overshadowed by the speculative schemes of large infrastructure projects - often decided by artificial or donor-defined needs. What, then, will be the use of surplus or unnecessary infrastructure or other non-housing schemes, when a mere heightening/stabilization of the plinth is adequate for sustaining livelihoods?

We feel that physical upgrading priorities especially for the extreme poor, should hence be set in two fronts, which are more shared than exclusive of each other. Priority one: a continuation of UPPR's partnership approach should be supplemented by subsidies and extended more into housing/dwelling levels. For the most vulnerable and the poorest, social safety nets should also be provisioned simultaneously. Priority two: livelihood dimensions must be mainstreamed and integrated with all housing and non-housing upgrading initiatives.

\section{ACKNOWLEDGEMENTS}

This paper is co-authored by the Design Communication Studio course instructors and five of its students from the MScHS (Master of Science in Human Settlement) at Architecture Discipline, Khulna University. It is based on research conducted as part of this course. The authors would 
like to express their gratitude to Architecture Discipline for facilitating this research. Authors are also indebted to the inhabitants of Montu Colony and Kashipur Bastee, UNDP, Khulna and Prof. Tanjil Sowgat, URP Discipline, Khulna University for their valuable support during research.

\section{REFERENCES}

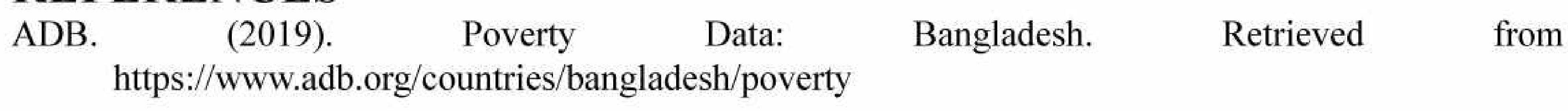

Alam, M.S., \& Mandal, M. (2019). Assessment of sanitation service quality in urban informal settlements of Khulna city based on SERVQUAL and AHP model: A case study of railway informal settlement, Khulna, Bangladesh. Journal of Urban Management, 8(1), 20-27.

Bah, E.M., Faye, I., \& Geh, Z.F. (2018). Informal settlement Upgrading and Housing Alternatives for the Poor. In Housing Market Dynamics in Africa. Macmillan, London: Palgrave.

Boonyabancha, S. (2009). Land for housing the poor-by the poor: experiences from the Baan Mankong nationwide informal settlement upgrading programme in Thailand. Environment and Urbanization, 21(2), 309-329.

BRAC. (2020). HOUSES FOR EVERYONE, BUILT BY EVERYONE. Retrieved from http://www.brac.net/publications/annual-report/2018/programmatic-area/pro-poor-urban-developm ent/

Creswell. (2009). QUALITATIVE INQUIRY and RESEARCH DESIGN Choosing Among Five Approaches (2nd ed.). Retrieved from: https://www.academia.edu/33813052/Second_Edition QUALITATIVE_INQUIRY_and_RESEARCH_DESIGN_Choosing_Among_Five_Approaches

CURE. (2005). City Wide Informal Settlement Mapping. Agra: City Development Strategy.

Fox, S. (2014). The political economy of informal settlements: Theory and evidence from Sub-Saharan Africa. World Development, 54, 191-203.

Ghafur, S. (2001). Beyond homemaking: The role of informal settlement improvement in home-based income generation in Bangladesh. Third World Planning Review, 23(2), 111-135.

Gough, K.V., \& Kellett, P. (2001). Housing consolidation and home-based income generation: evidence from self-help settlements in two Colombian cities. Cities, 18(4), 235-247.

Hakim, S. S. (2014). Control, Negotiation and Form of Migrants`Urban Home (PhD Thesis). National University of Singapore, Singapore.

Hill, Ruth, Genoni, \& Eugenia, M. (2019). Bangladesh Poverty Assessment. Retrieved from: http://documents.worldbank.org/curated/en/428911572583239007/Background-Papers

Harris, R., \& Arku, G. (2006). Housing and economic development: The evolution of an idea since 1945. Habitat International, 30, 1007-1017.

Jaitman, L., \& Brakarz, J. (2013). Evaluation of Informal settlement Upgrading Programs: Literature Review and Methodological Approaches. Retrieved from: https://pdfs.semanticscholar.org/d866/d29170a2a0c968ec07dfccdb6e782bb3db15.pdf

Jones, B. G. (2012). "'Bankable Slums': the global politics of slum upgrading". Third World Quarterly, 33(5), 769-789. 
Keefer, P., \& Khemani, S. (2004). Why do the poor receive poor services? Economic and Political Weekly, 935-943.

Lucci, P., Bhatkal, T., Khan, A., \& Berliner, T. (2015). What works in improving the living conditions of informal settlement dwellers. Retrieved from: https://www.odi.org/sites/odi.org.uk/files/odi-assets/publications-opinion-files/10188.pdf

Minnery, J., Argo, T.A., Winarso, H., Hau, D., Veneracion, C.C., Forbes, D., \& Childs, I. (2013). Informal settlement upgrading and urban governance: Case studies in three South East Asian cities. Habitat International, 39,162-169.

Mohit, M.A. (2012). Bastee Settlements of Dhaka City, Bangladesh: A Review of Policy Approaches and Challenges Ahead. Procedia - Social and Behavioural Sciences, 36, 611-622.

Mostafa, A. (2015). Evolution of Participatory and Support Based Approach for Strengthening Tenure Security, Housing and Community Resilience. Retrieved from: https://www.bd.undp.org/content/dam/bangladesh/docs/Projects/UPPR/nuppr/UPPR\%20Land\%20 Tenure\%20.pdf

Mpembamoto, K., Nchito, W., Siame, G., \& Wragg, E. (2017). Impact of sector-based upgrading on home-based enterprises: a case study of Chaisa Settlement. Environment and Urbanization, 29(2), 597-614.

Pamuk, A., \& Cavallieri, P.F.A. (1998). Alleviating urban poverty in a global city: new trends in upgrading Rio-de-Janeiro's Favelas. Habitat International, 22(4), 449-462.

Ramsamy, E. (2006), World Bank and Urban Development: From Projects to Policy. London: Routledge. doi.org/10.4324/9780203494080

Satterthwaite, D., \& Mitlin, D. (2013). Reducing Urban Poverty in the Global South. London: Routledge

Sheng, Y.K. (1989). Housing Priorities, Expenditure Patterns, and the Urban Poor in Third-World Countries. The Netherlands Journal of Housing and Environmental Research, 4(1), 5-15.

Tipple, A.G. (2005). The Place of Home-based Enterprises in the Informal Sector: Evidence from Cochabamba, New Delhi, Surabaya and Pretoria. Urban Studies, 42(4), 611-632. https://doi.org/10.1080/00420980500060178

Turner, C. F. J. (1972). Freedom to Build: Dweller Control of the Housing Process. New York: The Macmillan Company

Turner, J. F. C. (1976). Housing by people: Towards autonomy in building environments. New York, USA: Pantheon Books

UN Habitat. (2003). The Challenge of Slums. Retrieved from: https://unhabitat.org/sites/default/files/download-manager-files/The $\% 20$ Challenge $\% 20 \mathrm{of} \% 20$ Slum s\%20-\%20Global\%20Report\%20on\%20Human\%20Settlements\%202003.pdf

UN Habitat. (2012). State of the World's Cities 2012/2013: Prosperity of Cities.

United Nations Human Settlements Programme.

UN Habitat. (2014). A Practical Guide to Designing, Planning, and Executing Citywide Informal Settlement Upgrading Programmes. Retrieved from: https://uni.unhabitat.org/a-practical-guide-to-designing-planning-and-executing-citywide-informal settlement-upgrading-programmes/ 
UN Habitat. (2016). Informal settlements Almanac 2015-16, Tracking Improvement in the Lives of Informal settlement Dwellers. Participatory Informal settlement Upgrading Programme (PSUP). Retrieved

https://www.worldurbancampaign.org/sites/default/files/subsites/resources/Informal settlement\%20Almanac\%202015-2016\%20EN_16.02_web_0.pdf

UN (United Nations). (2015). Transforming our world: The 2030 agenda for sustainable development.

UN (United Nations). (2016). Country programme document for Bangladesh (2017-2020). Retrieved from https://digitallibrary.un.org/record/836580/files/DP_DCP_BGD_3-EN.pdf

Werthmann, C., \& Beardsley, J. (2008). Improving Informal Settlements: Ideas from Latin America". Retrieved

from:

http://www.harvarddesignmagazineorg/issues/28/improving-informal-settlements-ideas-from-latin -america

Wong, T. (2017). Developmentalism. Economic geography and regional development studies. Wiley Online Library. doi.org/10.1002/9781118786352.wbieg0185 